\title{
Judicial Disability and the Good Behavior Clause
}

\author{
Justice Douglas's retirement ended months of speculation about \\ his health and ability to remain on the Court. ${ }^{1}$ Coming at the end of \\ a decade during which the fitness of judges was increasingly examined, \\ his illness stimulated renewed consideration of judicial disability."
}

1. Justice Douglas suffered a stroke on December 31,1974 . He returned to the Court in October, 1975, but found he was unable to continue. On November 12, 1975, he retired under the provisions of 28 U.S.C. $\$ 371(\mathrm{~b})(1970)$. N.Y. Times, Nov. 13, 1975. at 60 , col. 2. For the wording of that section and the distinction between retirement and resignation, see note 7 infra. Accounts of his illness were given in NEwsweEk, July 7, 1975, at 46; TIME, Feb. 17, 1975, at 48; id. Apr. 7, 1975, at 58; id. July 7, 1975, at 44; U.S. NEws \& World Rer., May 26, 1975, at 69. For a contemporancous discussion of possible removal methods, see Reston, Mr. Justice Douglas, N.Y. Times, Scpt. 17, 1975 , at 45 , col. 5 .

2. In this Note "disability" or "incapacity" refers to a physical or mental condition which impairs a judge's ability to serve on the court.

A widely-publicized controversy over judicial fitness concerned Judge Stephen S. Chandler, Chief Judge of the Western District of Oklahoma. An order by the Judicial Council for the Tenth Gircuit that Chandler take part in no future proceedings prompted many discussions of judicial tenure in the legal literature. E.g., Note, Potential Limitations Upon the Tenure of Federal Trial Judges-Some Implications of the Chandler Case, 20 Sw. L.J. 667 (1966); Note, The Chandler Incident and Problems of Judicial Review, 19 STAN. L, REv. 448 (1967); Comment, Removal of Federal Judges-New Al. ternatives to an Old Problem: Chandler v. Judicial Council of the Tenth Circuit, 13 U.C.L.A. L. REv. 1385 (1966); Comment, Removal of Federal Judges-Alternatives to Impeachment, 20 VAND. L. REv. 723 (1967); 21 RUT. L. REV. 153 (1966).

In 1970 there were suggestions that the House of Representatives should investigate Justice Douglas's conduct to determine if it would be appropriate to initiate impeachment proceedings. 116 CoNG. REc. 11912-27 (1970): "That discussion led to a similar burst of discussion of judicial tenure. E.g., Berger, Impeachment of Judges and "Good Behavior" Tenure, 79 YALE L.J. 1475 (1970); Feerick, Inpeaching Federal Judges: $A$ Study of the Constitutional Provisions, 39 Fordham L. Rev. I (1970); Thompson \& Pollitt, Impeachment of Federal Judges: An Historical Overview, 49 N.G. L. Rev. 87 (1970).

The problem of unfit judges has a long history. A list of all "federal judges whose official conduct had been the subject of congressional inquiry" before 1962 is printed in J. Borkin, The Corrupt JudGe 219-58 (1962). Two periodicals have devoted entire issues to the problem: Judicial Ethics, 35 LAw \& Contrmp. Prob. 1 (1970); Judicial Mis. conduct, 48 J. AM. Jun. Soc'Y 163 (1965).

On a number of occasions congressional committees have held hearings related to judicial fitness. Hearings on Judicial Disqualification before the Subcomm. on Improvements in Judicial Machinery of the Senate Comm. on the Judiciary, 93d Cong., 1st Sess. (1973); Hearings on Reconfirmation of Federal Judges before the Subcomm. on Constitutional Amendments of the Senate Comm. on the Judiciary, 92d Cong., 2d Sess. (1973); Hearings on the Independence of Federal Judges before the Subcomm. on Separation of Powers of the Senate Comm. on the Judiciary, 91st Cong., 2d Sess. (1970) (including comprehensive bibliography on the subject of federal judges at 942-49); Hearings on Retirement of Justices and Judges before Subcomm. No. 5 of the House Comm. on the Judiciary, 91st Cong., 2d Sess., Ser. 16 (1970); Hearings on the Judicial Reform Act before the Subcomm. on Improyements in Judicial Machinery of the Senate Comm. on the Judiciary, 91st Cong., 1st \& 2d Sess. (1969, 1970); Hearings on Nonjudicial Activities of Supreme Court Justices and Other Federal Judges before the Subcomm. on Separation of Powers of the Senate Comm. on the Judiciary, 91st Cong., 1st Sess. (1969). 
Numerous remedies have been suggested. ${ }^{3}$ Two examples of such proposals in the present Congress are S. 1110 and H.R. 10439.4 S. 1110 would establish a Council on Judicial Tenure composed of judges in regular active service. The proposed Council would receive complaints about judges, conduct investigations, and report to the Judicial Conference of the United States. If a report recommended removal, the Council would present the evidence to a committee of the Conference. The Conference, or its committee, would have the power to order the censure, removal, or involuntary retirement of any judge or Justice of the United States.

The proposed legislation is premised on the theory that the Constitution, and in particular the good behavior clause, ${ }^{5}$ permits the removal of disabled judges. ${ }^{6}$ This Note focuses on the good behavior clause and argues that the Constitution does not allow the removal

3. The most varied proposals have been made in the states. A comparative study of five states is W. Braithwaite, Who Jubges the Judges? (1971). The removal provisions for each state are listed in Gasperini, Anderson \& McGinley, Judicial Removal in New York: A New Look, 40 FordhaM L. Rev. 1, 37.40 (1971). Other discussions of state removal provisions include Hall, Judicial Removal for Off-Bench Behavior: Why?, 21 J. Pub. LAw 127 (1972); Note, Remedies for Judicial Misconduct and Disability: Removal and Discipline of Judges, 41 N.Y.U. L. REv. 149 (1966).

4. S. 1110, 94th Cong., lst Sess. (1975), is printed at 121 Cong. Rec. S3407 (daily ed. Mar. 7, 1975). Hearings were held in February, 1976, before the Subcommittee on Improvements in Judicial Machinery of the Senate Judiciary Committec. 1 CCH Conc. INDEX 94 TH Cong. at 2514 (Mar. 17, 1976).

H.R. 10439, 94th Cong., lst Sess. (1975) is printed at 121 Conc. Rec. H5669 (daily ed. Oct. 30, 1975). H.R. 10439, which is considerably less detailed than the Senate bill, would authorize the Chief Justice to select a three-judge panel to investigate the behavior of any judge or Justice. If the panel determined the behavior was "not good," the judge or Justice would cease to hold office. The bill's sponsor suggested that evaluation of behavior should include physical capacity and attentiveness to duty. Id. (Rep. Findley). No hearings have been held on the House bill.

5. U.S. CoNsr. art. III, $\$ I$.

6. Raoul Berger is the most recent scholar to advocate this position. His argument consists of two basic points: (1) impeachment is not the exclusive removal mechanism for judges and (2) disabled judges are incapable of good behavior and may therefore be removed. That argument first appeared in Berger, supra note 2. It was published in a slightly modified form in R. Berger, Impenchment: The Constrtutional Problems 91, 122-92 (1973), and advanced in support of $S$. 1110 in Statement of Raoul Berger submitted to the Subcomm. on Improvements in Judicial Machinery of the Senate Comm. on the Judiciary, 94th Cong., 2d Sess. (Feb. 26, 1976) (on file with Yale Law Journal).

As Berger acknowledged, the argument did not originate with him. Professor Burke Shartel was the first to support the position with extensive research. Shartel, Federal Judges-Appointment, Supervision, and Removal-Some Possibilities under the Constitution, 28 Mich. L. REv. 870 (1930) [hereinafter cited as Federal Judges]; Shartel, Retirement and Removal of Judges, 20 J. AM. Jud. Soc'y 133 (1936). The same proposal in less detailed form was made in A. Simpson, A Treatise on Federal IMpeachments 74-75 (1916). Critics of Shartel include Kurland, The Constitution and the Tenure of Federal Judges: Some Notes from History, 36 U. CHI. L. Rev. 665 (1969); Otis, A Proposed Tribunal: Is It Constitutional? 7 U. KAN. CrTY L. REv. 3 (1938); Ziskind, Judicial Tenure in the American Constitution: English and American Precedents, 1969 S. Cr. REv. 135. 
of Justices or judges for disability and that no provision should be made for the replacement of a disabled Supreme Court Justice. ${ }^{7}$

\section{Removal for Disability under the Constitution}

The tenure of all federal judges is established by the good behavior clause of Article III, $\S 1$ of the Constitution:

The Judges, both of the supreme and inferior Courts, shall hold their office during good Behaviour and shall at stated Times receive for their Service a Compensation which shall not be diminished during their Continuance in office.

Supporters of proposals such as S. 1110 contend that a judge who is disabled is not behaving well and may therefore be removed. Whether a disabled judge may be removed depends, of course, upon the meaning of holding office "during good Behaviour." Because the Framers took that phrase directly from English law, its meaning in England provides important evidence of its meaning in the Constitution.

\section{A. The English History}

Before 1701 the tenure of English judges was fixed by the Crown. Each judge was appointed by individual letters patent in which the king defined the tenure of the office. Although some judges were appointed "during good behaviour," the more common tenure was during the king's pleasure: those judges could be removed whenever the king desired. ${ }^{\mathrm{S}}$ In 1701 , however, Parliament broke with that tradition and passed the Act of Settlement which regularized judicial

7. A judge is removed when he is deprived of office; there are no provisions in current federal statutes for removal of judges. A judge is replaced when his disability leads to the appointment of an additional judge to sit on the same court.

Statutory provisions for resignation, retirement, and replacement of federal judges are included in 28 U.S.C. $\$ 372(1970)$. Subsection (a) permits the retirement of a judge or Justice who has become "permanenty disabled from performing his duties . . . ." Any judge wishing to retire under that provision must furnish two certificates of disability to the President: one from the retiree and one from the Chief Justice or the chief judge as specified. Subsection (b) permits the President to appoint an additional judge when a judge found to be disabled does not retire. There is no provision for replacement of a Justice of the Supreme Court.

The Judicial Code distinguishes resignation from retirement. A judge or Justice who resigns severs all connection with the court; he ceases to hold his office. After resignation he continues to receive the salary he was paid at the time he resigned. 28 U.S.C. $\$ 371(a)(1970)$. A judge or Justice who retires continues to hold his office and may accept assignments on various courts. He receives the salary for the office which he holds. 28 U.S.C. $\S \S 294,371($ b) $(1970)$.

8. H. Gecil, Tipping THE Scales $25-27$ (1964); Mcllwain, The Tenure of English Judges, 7 AM. PoL. ScI. Rev. 217, 219-21 (1913). 
tenure by providing that in the future judges' commissions would "be made Quam diu se bene Gesserint [during good behavior], and their Salaries ascertained and established; but upon the address of both houses of parliament it may be lawful to remove them."9

Even before the exact meaning of "during good behavior" is defined, it is apparent that the Act of Settlement was fundamentally a restriction on the Crown's power to remove judges. All that remained was the power to remove after receiving an address from both houses of Parliament. In effect, judges were made independent of the Crown since they no longer had to depend upon royal approval for their tenure. ${ }^{10}$

Further understanding of the Act of Settlement depends upon the meaning of "good behavior" both before and after the passage of the Act. The meaning of the term was at issue whenever there was a challenge to the right to continue holding an office with good behavior tenure. At common law the mechanism used to test the conditions of any patent was the writ of scire facias.11 That writ, however, was merely a mechanism for determining whether the officeholder was fulfilling the substantive conditions of tenure, conditions which came not from the writ but from the terms of the patent itself (for example, tenure during good behavior). There are few challenges to good behavior tenure in the reported English cases. ${ }^{12}$ No judge was ever removed by the writ. Nevertheless, the cases do show that disability alone was never held to be cause for forfeiture of an office with good behavior tenure.

The fullest discussion of the protections afforded by good behavior tenure before the Act of Settlement occurred in Harcourt $v$. Fox. ${ }^{13}$

9. Act of Settlement $1701,12 \& 13$ Will. 3, c. 2. An address is a formal communication of opinion sent to the Crown after being approved by both houses of Parliament. For the form of an address, see E. May, The Law, Privileges, Proceedings and Usage of Parliament 828-33 (E. Fellowes \& T. Cocks eds. 16th ed. 1957).

10. H. Cecil, supra note 8, at 67-89; W. Gwyn, The Meaning of the Separation of Powers 7 (Tulane Studies in Political Science vol. IX, 1965); 1 A. TODD, ON PARLiAMENTARY GovernMent in ENGLand 571 (2d ed. 1887); M. Vile, Constitutionalism AND the Separation of Powers 29-32 (1967); Holdsworth, The Constitutional Position of the Judges, 48 L.Q. REv. 25, 29 (1932).

11. J. Chitty, A Treatise on the Law of the Prerogatives of the Crown; and the Relative Duties and Rights of the Subject 82-87, 330-31 (1820); C. Sweet, A DicTIONARY OF ENGLISH LAW 738 (1882).

12. A collection of scire facias cases, none of which involves good behavior tenure, is reported at 2 Dyer $197 \mathrm{~b}-198 \mathrm{~b}, 73$ Eng. Rep. $435-38$ (K.B. 1561). Shartel conceded that the English scire facias cases provided no evidence to support the conclusion that disability was a cause for removal from offices held during good behavior. Federal Judges, supra note 6 , at $899-900$.

13. 1 Show. 506, 89 Eng. Rep. 720 (K.B. 1693), aff'd, Show. P.C. 158, 1 Eng. Rep. 107 (H.L. 1693). Arguments of counsel are reported in 1 Show. at 426, 89 Eng. Rep. at 680 (K.B. 1692). 
The case involved conflicting claims to the office of clerk of the peace. The first appointee, Harcourt, sued a later appointee, Fox, for money (fees) had and received. Before Fox was appointed, a statute had made the office one held "for so long a time only as such Clerk of the Peace shall well demean himself in his said office."14 The statute further provided for the removal of the clerk for "misdemeanor."15 Since Harcourt had not "misdemeaned himself," the court decided he was entitled to the fees. In argument before the court, the attorney general equated the clerk's tenure with good behavior tenure. The clerk held office "quamdiu se bene gesserit," the attorney general explained, "that is, during life, unless he forfeits it by misdemeanour ...."16 Chief Justice Holt echoed that explanation and stated the tenure was "determinable only upon misbehaviour."17 The ready substitution of "misbehaviour" for "misdemeanour" suggests that the speakers considered the terms synonymous. At common law a "misdemeanor" was a criminal act.1s And not even the most expansive interpretation of criminal acts would include disability. Whatever the scope of common law crimes, ${ }^{19}$ forfeiture of a good behavior office required something more than disability.

Cases decided after the Act of Settlement provide no fuller definition of the meaning of good behavior tenure. The evidence which is available, however, is entirely consistent with earlier statements that more than disability was required for removal. $R$. $v$. Corporation of $W$ ells $^{20}$ was a case involving a request for a writ of mandamus to order the corporation to restore John Burland to the office of recorder, which he held during good behavior. Burland was accused of "repeated non-attendance" at both regular and special sessions of the corporation. Lord Mansfield described the reasons for which good behavior tenure could be forfeited: "Indeed, a general neglect, or refusal to attend the duty of such an office, is a reason of forfeiture: a determined neglect, a wilful refusal." ${ }^{21}$ Later he approved the statement "that the bare being absent, is not a cause of forfeiture."22

14. 1 W. \& M., c. $21, \S 5$ (1688).

15. Id. $\$ 6$.

16. I Show. at 556, 89 Eng. Rep. at 750.

17. Id. at 536, 89 Eng. Rep. at 734 .

18. C. SweEt, supra note 11 , at 530-31; 4 W. Blackstone, Commentaries *5.

19. To be sure, the common law did not define criminal conduct as specifically as do modern statutes. See, e.g., 8 W. Holdsworth, A History of ENGLish Law 302-05 (2d ed. 1937). However, that does not detract from the point that some form of misconduct was required for removal from a good behavior office.

20. 4 Burr. 1999, 98 Eng. Rep. 41 (K.B. 1767).

21. Id. at 2004, 98 Eng. Rep. at 44.

22. Id. at 2005, 98 Eng. Rep. at 45. 
If "bare" absence was insufficient for removal, so must have been "bare" disability.

In the same case Lord Mansfield rejected as too broad a statement made by Coke in his Commentaries on Littleton. Coke had written that "non-user of publique offices which concern the administration of justice, or the common wealth, is of it selfe a cause of forfeiture."23 Although Coke was not writing about judicial officers with good behavior tenure, his statement has been interpreted as support for the contention that judges are removable for disability. ${ }^{24}$ But the phrase "non-user" was a technical term associated with real property, ${ }^{25}$ and Coke's use of such a term without qualification indicates that the words retained their established meaning in this novel context. That meaning is consistent with Lord Mansfield's holding that more than absence was required. The standard English treatise on easements explained that "a mere intermittance of the user, or a slight alteration in the mode of enjoyment, when unaccompanied by any intention to renounce the acquisition of a right, does not amount to an abandonment."26

Lord Mansfield explained that it was incorrect to read Coke's statement as requiring no more than absence for forfeiture:

And some have gone so far as to hold, that an office concerning the administration of justice or the commonwealth, shall be forfeited for a bare non-user, whether any special damage be occasioned thereby or not. But this opinion doth not appeal to be warranted by any resolution in point; and the authorities which are cited to maintain it, do not seem to come up to it. ${ }^{27}$

Furthermore, Coke himself described forfeiture as resulting from doing "a thing against or without law or custome ...." $28 \mathrm{He}$ also wrote that when an "officer relinquisheth his office, and refuseth to attend, he loseth his office, fee, profit, and all."29 Understood in context,

23. COKE ON LITtLETON 233a.

24. See R. BERGER, supra note 6, at 160-63.

25. Coke's use of a real property term was entirely consistent with the early English view that all offices were property. See W. CRuise, Digest of the Laws of EngLand Respecting Real Property 93 (4th ed. 1835); J. Joliffe, The Constitutional History of Medieval England 204-06, 485-87 (4th ed. 1967); D. KeIR, The Constitutional History of Modern Britain Since 1485 (9th ed. 1969).

26. C. Gale \& T. Whatzey, a Treatise on the Law of Easements 276 (E. Hammond ed. 1840); accord, C. SwEET, supra note 11, at 539.

27. 4 Burr. at 2004,98 Eng. Rep. at 44 . Lord Mansfield's statement seems to suggest, however, that forfeiture could follow if some definite harm were caused by the official's absence.

28. Coke on LitrLeton 59a.

29. Id. 233b (emphasis added). 
then, Coke's statement that forfeiture would lie for "non-user" supports the view that more than disability was required for removal.

Proponents of removal for disability argue that the writ of scire facias provides a mechanism for removing federal judges in the United States. ${ }^{30}$ The historical evidence shows this argument to be a questionable one. ${ }^{31}$ More importantly, the emphasis on the availability of scire facias obscures the true issue-the meaning of good behavior tenure as a substantive protection of office. Regardless of the mechanism of removal, the early English cases appear to have protected good behavior officeholders from removal for disability. And as the next section of this Note demonstrates, the contemporary understanding of the good behavior tenure clause when it was incorporated into the Constitution makes clear that federal judges are so protected.

\section{B. The American Understanding}

Nothing in the colonial period indicates a departure from the English understanding of the protection for officeholders afforded by good behavior tenure. In fact, the colonial experience mirrors English developments. Early colonial judges were appointed to serve

30. R. BERger, supra note 6, at 127-33.

31. There is extensive evidence that at the time the Constitution was adopted impeachment was thought to be the exclusive mechanism for removing officers with good behavior tenure; this was true even though the writ of scire facias was used in the colonies. Journal of the Courts of Common Right and Chancery of East New Jersey, 1683-1702, at 57 passim (P. Edsall ed. 1937). Blackstone's discussion of the use of the writ to repeal a patent, 3 W. BLACkstone, Commentaries $* 260-61$, would also have been known to the colonists.

Both Thomas Jefferson and Alexander Hamilton were familiar with the writ of scire facias through their law practices. The Commonplace BOoK OF ThOMas JefFerson 80 n.215 (G. Chinard ed. 1926); The Law Practice of Alexander Hamilton 72, 101.03, 162,180 (J. Goebel ed. 1964). Even so, both men thought impeachment was the only means of removing a judge with good behavior tenure. See Letter from Thomas Jefferson to George Wythe (July, 1776), reprinted in 2 The Writincs of Thomas Jefrerson 59-60 (P. Ford ed. 1893); Letter from Thomas Jefferson to James Pleasants (Dec. 26, 1821), reprinted in $10 \mathrm{id}$. at 198-99 (1899); The CoMplete JefFerson 1173 (S. Padover ed. 1943); 7 The Writings of Thomas Jefferson 192 (H. Washington ed. 1854); The Federalist No. 79, at 474 (C. Rossiter ed. 1961) (Hamilton).

Members of the First Congress agreed that judges with good behavior tenure could only be removed by impeachment. See, e.g., 1 Annals of Congress 389, 569 (Madison), 390-91 (Boudinot), 484 (White) (1789) (running head: "Gales \& Seaton's History of Debates in Congress"). Similar views were held by Thomas Paine. In a pamphlet written in 1805 urging reform of the Constitution, he was critical of the Constitution for releasing judges "from all responsibility, except for impeachment." 10 THE LIFE AND Works of Thomas Paine 267 (W. Van der Weyde ed. 1925).

For additional evidence that impeachment was thought to be the sole mechanism for removal, see note $\mathbf{5 3}$ infra. 
at the king's pleasure. ${ }^{32}$ By the mid-eighteenth century, however, the colonists recognized that good behavior tenure was the cornerstone of judicial independence. ${ }^{33}$ Indicative of the colonists' awareness of the significance of the Act of Settlement and of their knowledge of English legal precedents was a series of articles in the Massachusetts Gazette in 1773. There, John Adams argued that judicial good behavior tenure was mandated by the Act of Settlement and not by the common law. ${ }^{34}$

Additional evidence of the importance which Americans attached to good behavior tenure can be found in Thomas Jefferson's 1776 drafts of the first Virginia state constitution. They provided that all judges were to serve during good behavior and further that lower court judges could be removed by the highest court for breach of good behavior. The judges of the highest court were in turn removable by the legislature for a similar breach. ${ }^{35}$ Years later, Jefferson complained that these provisions in the Virginia constitution had made judges "independent of the nation itself ... [and] irremovable, but by their own body, for any depravities of conduct, and even by their own body for the imbecilities of dotage." 36

Jefferson's statement that good behavior officers were not removable for incapacity was but one example of the widespread American belief. Another example can be found in the 1780 impeachment trial of Judge Francis Hopkinson of Pennsylvania. In its opinion the Pennsylvania Supreme Executive Council wrote, "In the first place

32. See, e.g., L. Larabee, Royal Government in America 388-400 (1930); G. Washburne, Imperial Control of the Administration of Justice in tile Thirteen Colonies 1684-1776, at 20, 178 (Studies in History, Economics and Public Law, Columbia University, vol. CV, no. 2, 1923). As recently as 1953, British colonial judges still held office at the Queen's pleasure. Terrell v. Secretary of State for the Colonies, [1953] 2 O.B. 482.

33. See, e.g., Journal of the Courts of Common Right and Chancery of East New JERSEY 1683-1702, at 18-19 (P. Edsall ed. 1937); H. ScotT, ThE CourTs of THE STATE of New YoRk 134-37 (1909); A Letter to the People of Pennsylvania, 1760, reprinted in Pamphlets of the American Revolution 248 (B. Bailyn ed. 1965).

Two English writers who were influential in America also believed in the necessity of good behavior tenure for judges. Blackstone wrote on the importance of an independent judiciary. 1 W. Blackstone, Commentaries *267, *269. Blackstone's successor at Oxford, Wooddeson, had similar thoughts about the Act of Settlement. 1 R. WoodDESON, A Systearatical View of the Laws of England 88 (1792).

34. On the Independence of the Judiciary: $A$ Controversy between William Brattle and Joln Adams, reprinted in 3 The Works of JoHN AdAMs 511 (C. Adams ed. 1851).

35. 1 The Papers of Thom.ss Jefferson 343, 351, 361 (J. Boyd ed. 1950). Jefferson's removal provisions were included in the impeachment clauses of the Virginia constitution as approved. The text of that constitution is printed in $2 \mathrm{~B}$. POORE, THE Feneral and State Constitutions, Colonial Charters, and other Organic Laws of THE UNITED States 1910 (2d ed. 1878).

36. Letter from Thomas Jefferson to Samuel Kercheval, July 12, 1816, reprinted in 10 The Wrimings of Thomas Jefferson 38 (P. Ford ed. 1899). 
it is observable, that the commission of the Judge is during good behaviour; crimes only are causes of removal . ..."'3t The juxtaposition of "crimes" and "good behaviour" made it clear that the mechanism for removal was irrelevant; no one could be removed from a good behavior office without having committed a crime. That opinion merely reiterates what had been said a century earlier in the English courts. ${ }^{38}$

Thus at the time of the Constitutional Convention both the English and the Americans thought good behavior tenure excluded removal for disability. As Alexander Hanson, a proponent of the Constitution, explained in 1788, good behavior in a judge was not an ambiguous concept, but one related "to the laws, and things universally known." 39 That shared understanding was reflected in the Convention's unanimity on the tenure for federal judges. ${ }^{40}$ In England judges were removable by an address of both houses of Parliament. ${ }^{41}$ But in their desire to insulate the judiciary even more and to eliminate any discretionary element in the legislature, the Framers rejected removal by address. Gouverneur Morris, for example, thought "it was fundamentally wrong to subject Judges to so arbitrary an authority"; Edmund Randolph "opposed the motion as weakening too much the independence of the Judges"; and James Wilson of Pennsylvania said, "The judges would be in a bad situation if made to depend

37. Trial of Francis Horkinson 1780, in Pennsylvania State Trials 56 (E. Hogan ed. 1794). In 1786 the General Assembly of Rhode Island expressed a similar view after initiating impeachment proceedings against the judges of the supreme court for their judgment in a case. Although a large majority of the Assembly voted that the judges had not given satisfactory reasons for the judgment, the Assembly felt it could take no action since the judges were not charged with criminal conduct. 4 American State Trials 584, 597-99 (J. Lawson ed. 1915).

38. See Harcourt v. Fox, 1 Show. 506, 89 Eng. Rep. 720 (K.B. 1693), aff'd, Show. P. C. 158, 1 Eng. Rep. 107 (H.I. 1693); pp. 709-10 supra.

39. A. Hanson, Remarks on the Proposed Plan of a Federal Government (1788), reprinted in 47 MAGAzine OF HistoRy 61, 79 (1933).

40. Even though the states were not uniform in their provisions for judicial tenure, all of the proposals at the Constitutional Convention contained the same tenure provisions for the federal judiciary. See 1 M. Farrand, The Records of the FederiL Conventron of 1787, at 21 (rev. ed. 1937) (Virginia Plan) [hereinafter cited as Farrand; id. at 244 (New Jersey Plan); 3 id. at 600 (draft attributed to Charles Pinckney); id. at 621, 625 (Alexander Hamilton); B. LoNG, Genesis of THE Constrtution of the United States of America 189.90 (1926); A Nevins, The American States During and after the REvolution 1775-1789, at 166-67 (1924); Ziskind, supra note 6, at 135.

The explanation for this unanimity is probably that the Framers were influenced by the English national structure rather than by the states. Support for that conclusion comes from the complaint in the Declaration of Independence that the king had "made judges dependent on his will alone, for the tenure of their offices, and the amount and payment of their salaries." S. Doc. No. 93-1, 93d Cong., Ist Sess. 585, 587 (1973) (Declaration reprinted). For discussion of the drafting of that provision, see E. DuMBsuld, The Declaration of Independence 112 (1950).

41. See pp. 708-09 supra. 
upon every gust of faction which might prevail in the two branches of our Govt." 42

The general acceptance of the principle that federal judges should serve during good behavior meant their tenure received little discussion either at the Convention or in the ratification debates. ${ }^{43}$ One opponent of the Constitution, however, recognized the implication of the tenure provisions of Article III, $\S 1$, and complained, "There is no authority that can remove them from office for any errors or want of capacity, or lower their salaries, and in many cases their power is superior to that of the legislature." 44 The order of the statement (tenure followed by salary provisions) indicates that the author was referring to the good behavior clause. Had the Constitution's defenders disagreed with this statement they could have argued that the statement was founded upon a misunderstanding of the clause. But they did not adopt that tactic. Instead, Hamilton argued in The Federalist that the ban on removal for disability was desirable:

The want of a provision for removing the judges on account of inability has been a subject of complaint. But all considerate men will be sensible that such a provision would either not be practiced upon or would be more liable to abuse than calculated to answer any good purpose. The mensuration of the faculties of the mind has, I believe, no place in the catalogue of known arts. An attempt to fix the boundary between the regions of ability and inability would much oftener give scope to personal and party attachments and enmities than advance the interests of justice or the public good. The result, except in the case of

42. 2 FARRAND, supra note 40, at 428-29. Removal for disability was mentioned only during debate on a motion that the chief executive "be removeable on impeachment and conviction <for > malpractice or neglect of duty.' "Id. at 64. The debate concerned the Presidency, an office held for a term of years; at no time was good behavior tenure discussed. James Madison "thought it indispensible that some provision should be made for defending the Community agst the incapacity, negligence or perfidy of the chief Magistrate. The limitation of the period of his service, was not a sufficient security." Id. at 65 (emphasis added). Gouverneur Morris was the other person who mentioned disability. He began his remarks by distinguishing the executive from the judiciary: "Our Executive was not like a Magistrate having a life interest ...." Id. at 68. He continued, "The Executive ought therefore to be impeachable for treachery; Corrupting his electors, and incapacity were other causes of impeachment." Id. at 69 (emphasis added).

43. In the Pennsylvania ratification convention, for example, James Wilson, a Framer and later a Justice of the Supreme Court of the United States, said, "I hear no objection made to the tenure by which the judges hold their offices." J. Wilson, Commentaries on the Constitution of the United States of America 95 (T. Lloyd ed. 1792).

44. The Antifederalist Papers 224 (M. Borden ed. 1965) (emphasis added). The comment was signed "Brutus," who was described by Borden as the "most brilliant of all Antifederalist writers." Id. at 42. There is disagreement over the identity of "Brutus." He has been identified as either Thomas Treadwell or Robert Yates. Id. at 42; J. MAIN, The ANTI-FEDERALISTS 117, 287 (1961). 
insanity, must for the most part be arbitrary; and insanity, without any formal or express provision, may be safely pronounced to be a virtual disqualification. ${ }^{45}$

For present purposes, the most striking feature of this exchange between opponents and supporters of the Constitution is not their differences over the merits of good behavior tenure for judges, but their common understanding that the grant of such tenure precluded removal for incapacity.

Following the Constitutional Convention there were repeated confirmations of the widespread understanding of the protection afforded by good behavior tenure. In 1789 the First Congress debated the President's power to remove executive officials. The central issue in that debate was whether the Constitution required that impeachment be the only means of removing executive officials other than the President and Vice President. Throughout the debate the speakers contrasted executive officials with judges who held office during good behavior: for the former there was no limitation on the causes of removal; for the latter the causes were restricted by their tenure.

Although there was no agreement on the extent of the President's power to remove executive officials, there was a uniform understanding that the good behavior clause meant that judges were not re-

45. The Federalisr No. 79, at 474 (C. Rossiter ed. 1961). Berger reads Hamilton's last sentence to say that insanity was a cause for removal. $R$. BERGER, supra note 6 , at 139,184 . In fact, the paragraph taken as a whole demonstrates the contrary. Hamilton was defending the absence of a provision for removal of judges for disability by arguing that such a provision would lead to arbitrary results except in the case of insanity; even in this case, he contended, the provision would be unnecessary because the judge would be "virtually" disqualified. His use of the word "virtual" in a passage about removal indicates that he meant something other than "actual" removal-perhaps a disqualitication in the sense of no longer being able to function as a judge.

Some 50 years later, Justice Story echoed Hamilton's argument against a provision for removal for disability:

But all considerate persons will readily perceive, that such a provision would either not be practised upon, or would be more liable to abuse, than calculated to answer any good purpose. . . An attempt to fix the boundaries between the region of ability and inability would much oftener give rise to personal, or party attachments and hostilities, than advance the interests of justice, or the public good. And instances of absolute imbecility would be too rare to justify the introduction of so dangerous a provision.

3 J. Story, Commentaries on the Constitution 486 (1833). Story's last sentence makes clear that insanity-or in his words, "absolute imbecility"-would not be cause for removal absent the "dangerous provision."

Berger also interprets Hamilton's last sentence as assuming the existence of a removal process other than impeachment. R. BERGER, supra note 6, at 184. This position is contradicted by Hamilton's own words in the paragraph preceding the one quoted in the text; in that paragraph he wrote that impeachment was the only removal process for judges. THE FEDERALIST No. 79 , supra at 474 , quoted in note 53 infra. 
movable for disability. ${ }^{4 B}$ Representative William Smith asked, "What must be done if an incumbent [good behavior officeholder] is found unfit for his office? He would answer, the person must remain there." ${ }^{47}$ Samuel Livermore said of judges with good behavior tenure, "[T]hey have an inheritance which they cannot be divested of, but on conviction of some crime." $\$ 8$ Two other speakers also directly addressed the issue of a disabled judge. John Lawrence said that good behavior tenure meant the officers were not removable for disability alone. "We are told," he said, "that an officer must misbehave before he can be removed. This is true with respect to those officers who hold their commissions during good behavior, but it cannot be true of those who are appointed during pleasure, they may be removed for incapacity, . . ." \pm 0 Representative Jackson inquired whether a judge rendered unfit by a stroke could be removed. He answered his own question: "Not for this cause, it is impossible; because madness is no treason, crime or misdemeanor. If he does not choose to resign, like Lord Mansfield, he may continue in office for ninety or one hundred years, although seldom so long have any men retained their faculties."

Fifteen years after those debates the House voted to impeach District Judge John Pickering, a man who all agreed was insane. ${ }^{51}$ Rather than charge him with mere disability by virtue of his insanity, however, the House accused him of specific misdeeds. And Pickering's insanity was used as a defense to the charges ${ }^{52}$-compelling evidence of the belief that disability was not a ground for removal. Anyone who thought disability was cause for removal could have adopted the statements of Pickering's defenders. But no one did so. ${ }^{53}$

46. See, e.g., I ANnals of Congress 389, 569 (Madison), 390-91 (Boudinot), 477 (Huntington), 484 (White) (1789) (running head: “Gales \& Seaton's History of Debates in Congress").

47. Id, at 392 . Accord, id. at $475,489,528$.

48. Id. at 497. Accord, id. at 396.

49. Id. at 501. Accord, id. at 392 .

50. Id. at 507 .

51. 3 A. Beveridge, The Life of John Marshall 164-65 (1919), citing 13 annals of Congress 334-42 (1804) (depositions in the impeachment proceedings).

52. 13 ANNaLS OF CONGREsS 326-28 (1804).

53. Indirect support for the position that disability was not cause for removal from good behavior tenure offices comes from the widely held view that impeachment was the sole method for removing judges, see note 31 supra, and that impeachment did not lie for disability. For example, Hamilton wrote that judges

are liable to be impeached for malconduct by the House of Representatives and tried by the Senate; . . . This is the only provision on the point which is consistent with the necessary indenendence of the judicial character, and it is the only one which we find in our own Constitution in respect to our own judges.

The Federalist No. 79, at 474 (C. Rossiter ed. 1961).

Two influential early commentators on the Constitution who stressed that impeach- 
The Framers chose good behavior tenure to limit the power to remove judges and to ensure judicial independence. The entire history of good behavior tenure, both in England and in America, denies the possibility of removal for disability. Thus, insofar as proposals like S. $1110^{54}$ would permit the removal of a disabled judge, they violate the constitutional protection given to federal judges by the good behavior clause.

\section{Statutory Provisions}

The unconstitutionality of removal proposals does not foreclose the extension to Supreme Court Justices of the provisions in $\$ 372$ (b) of the Judicial Code for replacing disabled federal judges. ${ }^{\text {¿j }}$ Such an extension would allow the President to appoint an additional Justice whenever a sitting Justice became permanently disabled. Or Congress could itself enlarge the Court by one for each disabled Justice. Neither course would be unconstitutional, but either would be unwise.

The Framers realized that disability was so vague a concept that it would be utilized for political intrigues. ${ }^{56}$ Extension of $\S 372(\mathrm{~b})$ would create a risk of subjecting the Justices to the very pressures

ment was the sole method of removing judges also thought that impeachment would not lie for disability alone. Rawle wrote, "A commission granted during good bchaviour can only be revoked by this mode [impeachment] of proceeding," and

If a judge should be incapacitated by infirmity or age, or be otherwise, without any fault of his own, prevented from performing his duties, he would not be a proper subject for removal by impeachment; yet, where duties cannot be performed, the officer should not be continued.

W. Rawle, A View of the Constitution of the United States 218, 278 (2d ed. 1829). (The final clause in Rawle's sentence is admittedly ambiguous. But to interpret it as a statement that good behavior officers could be removed for disability by some means other than impeachment would contradict his earlier, explicit statement.) The other commentator, James Bayard, thought that judges were removable only by impeachment "for any abuse of their trust." J. BAYARD, A BRIEF EXPOSITION OF THE CONSTITUTION of THE United States 119 (2d ed. 1834).

Later recognition that impcachment did not lie for disability came when Congress was considering special bills to allow several Supreme Court Justices to retire. Sce note 64 infra. The debates on the bill to allow Justice Ward Hunt's retirement made clear that Congress did not think it could impeach Justice Hunt for disability. 13 Coxg. Rrc. 505-06, 612-18 (1882). The House report accompanying a similar bill for Justice William Moody explicitly rejected impeachment for disability:

There is no way of removing an associate justice from his office except by impeachment, and impeachment can be had only after conviction of high crimes and misdemeanors.

$\cdots \cdots$

A Judge may die, resign, or retire under the statute, but of course he can not, and should not, be impeached for ill health.

45 Cong. Rec. 8557 (1910).

54. 94th Cong., lst Sess. (1975); see p. 707 supra.

55. 28 U.S.C. $\$ 372(\mathrm{~b})(1970)$. See note 7 supra.

56. See pp. 714-16 supra. 
which the Framers sought to avoid. Lower federal courts are seldom important enough to warrant interference, and their number makes impractical any attempt to influence their decisions. But the Supreme Court is both more important and more easily manipulated; a single vote is often determinative. Similar considerations convinced the Congress not to extend the replacement provisions of $\S 372(\mathrm{~b})$ to the Supreme Court. ${ }^{57}$ On one occasion a President actually tried to interfere with the Court-Franklin Roosevelt's famous "court-packing" plan. ${ }^{58}$ On other occasions, a President might have been tempted to interfere, had a provision such as $\S 372(\mathrm{~b})$ been available. ${ }^{59}$ For example, Justice Howell Jackson's illness during the Income Tax Cases would have provided an opportunity for a political appointment. ${ }^{60}$ Justice Douglas's illness during an important capital punishment case ${ }^{61}$ was a similar instance.

Because the danger of Presidential tampering is a real one, it is important to consider the actual harm done by illness on the Supreme Court. Without a doubt a single Justice's absence can cause hardship on an already busy Court. ${ }^{62}$ But the frequency of disability on the Court is declining. Of the ninety-three past Justices at least fifteen suffered mental or physical incapacity for more than a year before leaving the Court. ${ }^{63}$ Over the past century, however, Congress

57. See 53 Cong. Rec. $2685-88$ and 54 Cong. REc. $42-52$ (debates on S. 706, 64th Cong., 1st \&: 2d Sess. (1916)).

58. See J. Alsop \& T. Catledge, The 168 Days (1938); L. Baker, Back to Back, The Duel Between FDR ANd THE SUPReMe Court (1967); Leuchtenburg, Franklin $D$. Roosevelt's Supreme Court "Packing" Plan, in Essays on THE New DeAL 69 (H. Hollingsworth \& W. Holmes eds. 1969). For an earlier instance, when a president considered altering judicial tenure as a reaction to a decision in an important antitrust case, see N.Y. Times, Mar. 24, 1906, at 1, col. 1 .

59. Congress has also been tempted to interfere with the composition and tenure of the judiciary. See W. Carpenter, Judicial Tenure in the United States v (1918). For discussion of some of those congressional attempts, see Holloman, The Judicial Reform Act: History, Analysis, and Comment, 35 LAw \& Contemp. Prob. 128, 130 (1970); Kurland, supra note 6, at 665-66; Nagel, Court-Curbing Periods in American History, 18 VAND. L. REv. 925 (1965).

60. Goff, Old Age and the Supreme Court, 4 AM. J. LEg. Hisr. 95, 101 (1960).

61. Fowler v. North Carolina, cert. granted, 419 U.S. 963 (1974), argued, 43 U.S.L.W. 3582 (U.S. Apr. 21, 1975), restored for reargument, 422 U.S. 1039 (1975).

62. The most recent illustration, of course, was provided by Justice Douglas. After his stroke the Court rescheduled eleven arguments for the fall term. NEwSWEEK, July 7,1975 , at 46 . It was also reported that the other Justices had agreed not to count his vote whenever it created the majority. TIME, July 7, 1975, at 44; N.Y. Times, July 13, $1975, \S 4$, at 2 , col. 1 ; id. July 8,1975 , at 17 , col. 1 .

Almost a century earlier the partial paralysis of Chief Justice Waite was alleged to have contributed to the Court's backlog of cases. N.Y. Times, Jan. 5, 1885, at 4, col. 4. Justice Moody's illness in 1910 also led to the reargument of important cases. 16 VA. L. REG. 218, 219 (1910).

63. Fifteen is a conservative estimate reached by reading all the obituaries and memorial services published in the official court reports and all news items about a Justice in the New York Times. For brief biographies of all the Justices, see THE. 
has liberalized the retirement provisions for judges. ${ }^{64}$ Of the Justices appointed this century, only William Moody remained on the Court after his disability became evident. ${ }^{65}$ Not since 1910 has an incapacitated Justice lingered on the Court. Furthermore, the Court appears to have developed an informal procedure whereby the other Justices suggest retirement to a Justice whose health or capabilities are failing. ${ }^{66}$ The dangers from additional appointments are great; the actual harm from judicial disability is slight. With that balance it would be better to leave the decision to retire to the individual Justice. The Framers were willing to accept the inconvenience of disability, and there is no convincing evidence that their choice was incorrect.

Justices of the United States Supreme Court 1789-1969 (L. Friedman \& F. Israel eds. 1969); other sources of information about disability on the Court include Fairman, The Retirement of Federal Judges, 51 HaRv. L. Rev. 397 (1938) (primarily nineteenth century Justices); and Goff, supra note 60.

64. In 1869 Congress authorized a pension for judges who retired after ten years' service. Act of April 10, 1869, ch. 22, $\$ 5,16$ Stat. 45 (codified at 28 U.S.C. $\$ \$ 371,372$ (1970)). Three times Congress specifically extended the statute to induce an ailing Justice to retire.

In January, 1882, Congress passed a bill extending the retirement provisions to Justice Ward Hunt, provided that he retire within thirty days. Act of Jan. 27, 1882, ch. 4, 22 Stat. 2. Justice Hunt resigned the day the bill was signed. 118 U.S. 701-02 (1886). A similar bill was passed for Justice William Moody. Act of June 23, 1910, ch. 377, 36 Stat. 1861. In his case, though, Congress allowed him five months to resign. The last special provision was passed for Justice Mahlon Pitney who had served a full ten years but had not yet reached age seventy. Act of Dec. 11, 1922, ch. 1, 42 Stat. 1063. See 64 CoNG. REC. 18 (1922).

In 1929 the statute was amended to require only a total of ten years' service (previously ten consecutive years had been required). Act of Mar. I, 1929, ch. 419, 45 Stat. 1422 (codified at 28 U.S.C. $\$ \S 371,372(1970)$ ). The reason for that amendment was to permit Chief Justice Taft to retire. N.Y. Times, Feb. 4, 1930, at 1, col. 8. The pension provisions have been liberalized since 1929. A judge may now retire with full pay at age sixty-five after fifteen years' judicial service or at seventy after ten; a disabled judge who has not served ten years may retire at half pay, 28 U.S.C. $\$ \$ 371$, 372 (1970).

65. See Goff, supra note 60, at 95. Some might include Justice Holmes as well. Id. at 104-06.

66. Justice Harlan's anecdote about Justice Field is probably the best known illustration of this informal procedure. Justice Field's abilities had been deteriorating for some time when the other Justices deputized Harlan to suggest retirement. Harlan's reluctance to mention retirement was heightened by Field's soporific state during their conversation. Nevertheless, Harlan broached the subject by recalling that Field himself had suggested resignation to Justice Grier in 1870. Then, according to Harlan,

The old man [Field] listened, gradually became alert and finally, with his cycs

blazing with the old fire of youth, he burst out:

"Yes! And a dirtier day's work I never did in my life!"

C. Hughes, The Supreme Court of the United States 75-76 (1928). In 1932 the other Justices suggested to Justice Holmes that he retire. Goff, supra note 60, at 106. 